\title{
The Effect of Exhibition Experience on the Intention of Purchase
}

\author{
Seung-Wan $\mathrm{Ju}^{1}$ and Lee-Sang Jung ${ }^{2}$ \\ ${ }^{1,2}$ Tong-Myung University, Korea \\ Igauace@naver.com, ${ }^{2}$ lsjung@tu.ac.kr
}

\begin{abstract}
Recently, exhibition industries are becoming high value-added service industries, with their high value in creating jobs and increasing income. Therefore, its effect on the economy is getting bigger, and many nations around the world are making effort to develop their exhibition industries. However, the awareness and research about corporate marketing exhibitions are insufficient, and the empirical study about its effect is also very lacking. As a result of the analysis, it has been found that amongst the four basic elements of exhibition experience, entertainment, educational, and deviating experience cause a significant effect on the experience satisfaction. In addition, all of these three experiences after the off-line exhibition experience increased the experience satisfaction and had a positive effect on the purchase intention. As a result, if the three factors were high, the purchase intention was also high.
\end{abstract}

Keywords: Exhibition, Corporate marketing exhibition hall, Exhibition experience, Experience economics theory, Experience satisfaction

\section{Introduction}

Recently, the corporate marketing exhibition hall is becoming more important, as it is leading customers' purchase behavior, brand asset management, and corporate image of the companies that are making efforts to manage long term customers and ever-changing customer satisfaction. However, the awareness and research about corporate marketing exhibitions are insufficient, and the empirical study about its effect is also very lacking.

Therefore, its research has focused on the effects of exhibition experience on experience satisfaction and purchase intent. By doing this, it suggests any improvement plan through its exhibition experience and any developmental direction of the corporate marketing exhibition hall. It needs to be developed into a place where it can satisfy many different needs of customers via increased communication and familiarity amongst the industries. It also needs to be developed into a place where it can provide cultural service to the customers and potential audience via high tech exhibition techniques, and a place where it can contribute to the community's culture. This study focuses on the ways to cause purchase behavior, enhance corporations' image, secure potential customers through the corporate marketing exhibition hall.

Article history:

Received (September 20, 2019), Review Result (October 16, 2019), Accepted (November 11, 2019) 


\section{Theoretical background}

\subsection{Exhibition}

The dictionary definition of the exhibition is "putting and showing many different items in one place", and the dictionary definition of the exhibition is "putting and showing many different items in one place", and it can be an act of sharing with the audience through displaying with the exhibition planner's interpretation.

The conventional meaning of exhibition is the arrangement of the unified unit of exhibits in one place and any interpretation of such exhibits. However, the concept of an exhibition in the precedent researches or literature is as follows.

Table 1. The concept of exhibition and display [1]

\begin{tabular}{|c|c|c|}
\hline & Exhibition & Display \\
\hline Origin & Exhibition or Exposition & Latin word “Displicare”(Appear, Open, Display) \\
\hline Expression & English - Exhibition & English - Display(Unfold, Express, Show) \\
\hline Content & Works such as painting & Goods, Work, Products \\
\hline Purpose & Nonprofit, Community Service & Commercial \\
\hline
\end{tabular}

Exhibition place is normally divided into permanent and non-permanent exhibition place. Permanent exhibitions include museums, promotion halls, and art galleries, etc., which have the main purpose to collect, store, and deliver information and are exhibited for the long term.

Table 2. Classification by exhibition space [2]

\begin{tabular}{|c|c|c|}
\hline Classification & Name & Characteristics \\
\hline \multirow{4}{*}{$\begin{array}{l}\text { Permanent } \\
\text { Exhibition }\end{array}$} & Museum & $\begin{array}{l}\text { A facility with a purpose to contribute to the community's education } \\
\text { and academic research, through collecting, preserving, displaying, and } \\
\text { exhibiting archaeological data, historical relics, and arts, etc. }\end{array}$ \\
\hline & Promotion Hall & $\begin{array}{l}\text { An exhibition space to introduce the corporation's image, history, } \\
\text { manufactured products, and technology, etc. }\end{array}$ \\
\hline & Memorial & $\begin{array}{l}\text { An exhibition space to commemorate a great historical figure or } \\
\text { historically significant event. }\end{array}$ \\
\hline & Science Museum & $\begin{array}{l}\text { An exhibition to introduce science-related facts through viewing, } \\
\text { experiencing, and experimenting with an installed exhibition that was } \\
\text { made based on scientific data or theory. }\end{array}$ \\
\hline \multirow{3}{*}{$\begin{array}{l}\text { Non- } \\
\text { permanent } \\
\text { Exhibition }\end{array}$} & EXPO & $\begin{array}{l}\text { It is a world EXPO where information or technology about art, science, } \\
\text { and industry, etc. are exhibited, which can lead to enhance the } \\
\text { promotion of the industry and expanding trade. }\end{array}$ \\
\hline & Trade Show & $\begin{array}{l}\text { This has a strong commercial characteristic. Most exhibitions held at } \\
\text { Seoul COEX, Seoul Trade Exhibition Center, and Busan's BEXCO, } \\
\text { etc. are trade shows. }\end{array}$ \\
\hline & Fair & $\begin{array}{l}\text { The main purpose is deals and trade. It has a strong market meaning } \\
\text { and comprises of many different parts, including regional, industry, } \\
\text { local, domestic, international, etc. }\end{array}$ \\
\hline
\end{tabular}

\subsection{Definition of the exhibition for corporations}

According to the intended purpose, the definition of the exhibition for corporations can be into four different areas: communication, promotion, marketing, and design.

Firstly, in the communication view, exhibition means two-way communication between the sender and the receiver. Secondly, in the promotion view, exhibition means a place where the 
corporation can show its image and its manufacturing products at the same time. Thirdly, in the marketing view, exhibition means a high-end industry where various marketing technique is aggregated. Fourthly, in the design view, exhibition means a space design that delivers the corporation's intended purpose for a designation period.

\subsection{Corporation promotion exhibition hall}

Corporation promotion exhibition halls are installed and operated by the corporation and are included in the corporation museum range. According to the classification regulated by the museum law, corporation museums include science museums, industrial technology museums, history museums, or folk museums. It is a professional museum that specializes in detailed collections [3].

\subsection{Exhibition experience}

Maslow (1994) defined experience as an enjoyable state of mind after experiencing something, and Van Maneb (1994) defined it as a recognizable state of mind after experiencing something [4].

Experience in exhibition means having delivered, understand, and recognize its intent through directly or indirectly participating or performing [5].

\subsection{Experience Economics Theory}

Pine \& Gilmore (1998) argued that the modern community has become an Experience Economy, and explained that there is a close relationship with the natural transition process of economic value, which consists of characteristics of economical products, general goods, products, services, and experience [6].

In addition, regarding one's experience, Pine \& Gilmore (1998) presented 4Es theory (Entertainment, Education, Escapist, Esthetics) based on two dimensions: degree of participation and relationship with the environment [7].

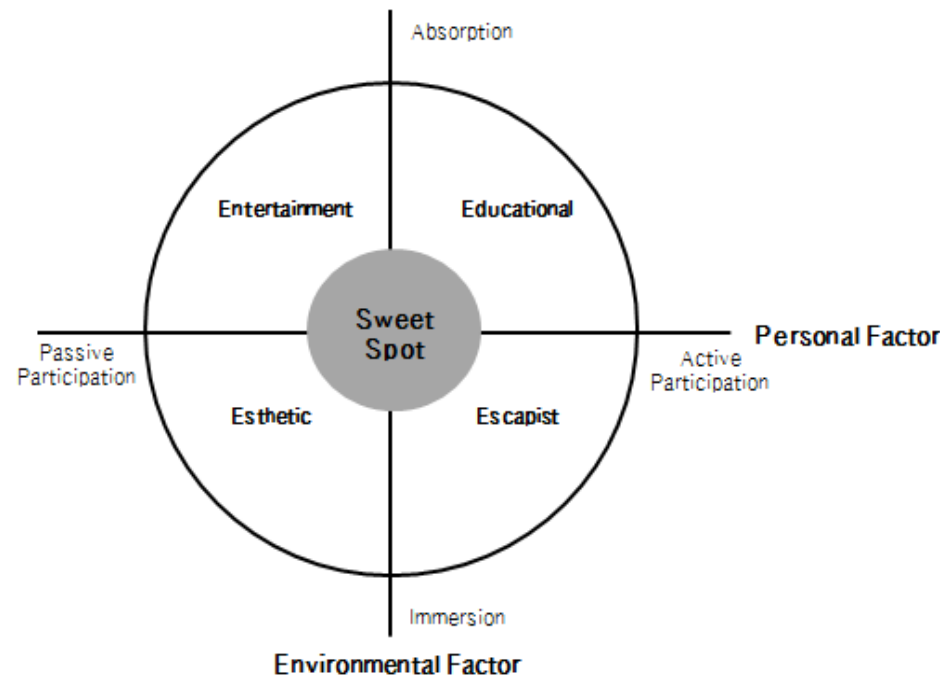

Figure 1. Pine and Gilmore's experience components[8] 


\subsection{Experience the satisfaction}

The concept of satisfaction is developed from psychology. Its dictionary definition means a state of being satisfied, without any lacking element. The concept of satisfaction has long been defined by many scholars in the business and tourism area.

\subsection{Purchase intention}

Purchase intent is defined as a person's rational judgment dimension, as it is a person's will and belief that are shown with future behavior after forming an attitude regarding a certain status.

\section{Research design}

To conduct this research, we conducted a survey targeted towards the audience who visited the corporate promotion exhibition hall and has experienced the exhibition. Based on literature and precedent research, we have set the following research model in [Figure 2] to review the effects. The exhibition experience has on experience satisfaction and purchases intent.

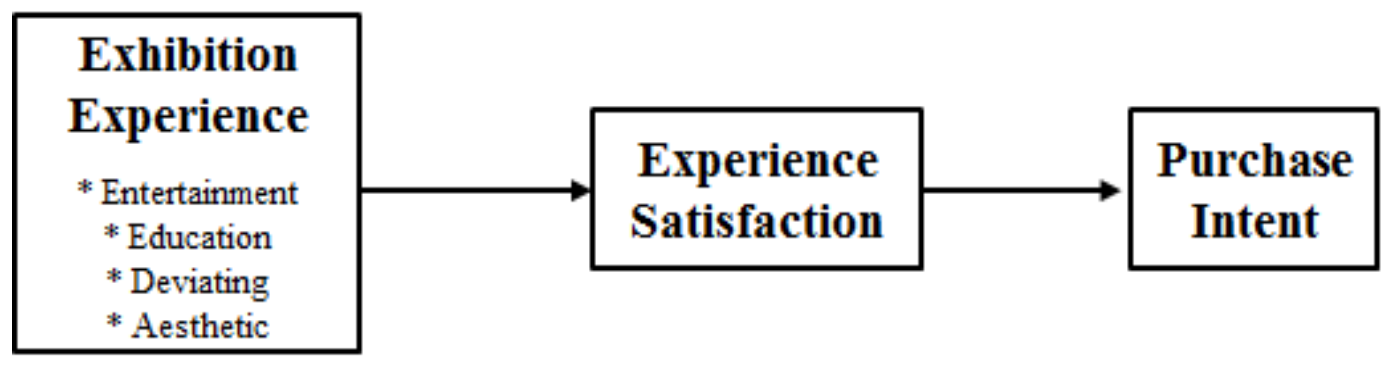

Figure 2. Research model

In this research, we aim to verify the following research model \& research hypothesis based on the premise that corporate promotion exhibition halls and exhibition experience will have a positive effect on the experience satisfaction and purchase intent.

[Hypothesis 1] Exhibition experience will have a positive effect on experience satisfaction.

H 1-1 Entertainment experience of the exhibition experience will have a positive effect on experience satisfaction.

H 1-2 Educational experience of the exhibition experience will have a positive effect on experience satisfaction.

H 1-3 Deviating the experience of the exhibition experience will have a positive effect on experience satisfaction.

H 1-4 Aesthetic experience of the exhibition experience will have a positive effect on experience satisfaction.

[Hypothesis 2] Experience satisfaction after exhibition experience will have a positive effect on purchase intent. 


\section{Empirical analysis}

If you take a close look at the analysis result of hypothesis 1, firstly, the non-standardization factor of entertainment experience was 0.271 , which is a statistically significant insignificance level $\mathrm{p}<0.001$. Secondly, the non-standardization factor of educational experience was 0.162 , which is statistically significant insignificant level $\mathrm{p}<0.01$. Thirdly, the non-standardization factor of deviating experience was 0.358 , which is statistically significant insignificant level $\mathrm{p}<0.001$. Fourthly, the relationship between the aesthetic experience and experience satisfaction is not statistically significant, and hypothesis 1-4 does not stand true.

Table 3. Analysis results of exhibition experience and experience satisfied

\begin{tabular}{|c|c|c|c|c|c|c|c|c|c|c|}
\hline \multirow[t]{2}{*}{ Model } & \multicolumn{2}{|c|}{$\begin{array}{c}\text { Non- } \\
\text { standardizati } \\
\text { on Factor }\end{array}$} & \multirow{2}{*}{$\begin{array}{c}\begin{array}{c}\text { Standar } \\
\text { dization } \\
\text { Factor }\end{array} \\
\text { Beta }\end{array}$} & \multirow[t]{2}{*}{$\mathrm{t}$} & \multicolumn{2}{|c|}{$\begin{array}{l}\text { Collinearity } \\
\text { Statistic }\end{array}$} & \multirow{2}{*}{$\begin{array}{c}\text { Analysi } \\
\text { s of } \\
\text { F }\end{array}$} & \multirow{2}{*}{$\begin{array}{c}\mathrm{R} \\
\text { Square }\end{array}$} & \multirow{2}{*}{$\begin{array}{c}\mathrm{R} \\
\text { Squar } \\
\mathrm{e} \\
\text { Variat } \\
\text { ion }\end{array}$} & \multirow{2}{*}{$\begin{array}{c}\text { Durbin } \\
- \\
\text { Watso } \\
n\end{array}$} \\
\hline & B & $\begin{array}{c}\begin{array}{c}\text { S.Er } \\
\text { ror }\end{array} \\
\end{array}$ & & & $\begin{array}{l}\text { Toler } \\
\text { ance }\end{array}$ & VIF & & & & \\
\hline (Constant) & .711 & .212 & & 3.353 & . & 2.162 & \multirow{5}{*}{$\begin{array}{c}94.039 \\
* * *\end{array}$} & \multirow{5}{*}{.579} & \multirow{5}{*}{.579} & \multirow{5}{*}{1.765} \\
\hline $\begin{array}{c}\text { Entertain } \\
\text { ment }\end{array}$ & .271 & .046 & .311 & $5.834 * * *$ & .462 & 2.162 & & & & \\
\hline $\begin{array}{c}\text { Education } \\
\text { al }\end{array}$ & .162 & .060 & -.071 & $2.709 * *$ & .496 & 2.017 & & & & \\
\hline Deviating & .358 & .085 & & $6.219 * * *$ &. .464 & 2.024 & & & & \\
\hline Aesthetic & .051 & .052 & .348 & .988 & .557 & 1.769 & & & & \\
\hline
\end{tabular}

If you take a close look at the analysis result of hypothesis 2 , the non-standardization factor of experience satisfaction was 1.011 , which is a statistically significant insignificant level $\mathrm{p}<0.001$, according to [Table 4].

Table 4. Analysis results of the experience satisfied and buying intention

\begin{tabular}{|c|c|c|c|c|c|c|c|c|c|c|}
\hline \multirow[t]{2}{*}{ Model } & \multicolumn{2}{|c|}{$\begin{array}{c}\text { Non- } \\
\text { standardizatio } \\
\text { n Factor }\end{array}$} & \multirow{2}{*}{ 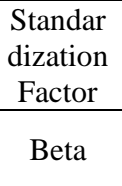 } & \multirow[t]{2}{*}{$\mathrm{t}$} & \multicolumn{2}{|c|}{$\begin{array}{c}\text { Collinearity } \\
\text { Statistic }\end{array}$} & \multirow{2}{*}{$\begin{array}{c}\text { Analysi } \\
\text { s of } \\
\text { F }\end{array}$} & \multirow{2}{*}{$\begin{array}{c}\mathrm{R} \\
\text { Squar } \\
\mathrm{e}\end{array}$} & \multirow{2}{*}{$\begin{array}{c}\mathrm{R} \\
\text { Squar } \\
\mathrm{e} \\
\text { Variat } \\
\text { ion }\end{array}$} & \multirow{2}{*}{$\begin{array}{c}\text { Durbi } \\
\text { n- } \\
\text { Watso } \\
\text { n }\end{array}$} \\
\hline & B & $\begin{array}{l}\text { S.Er } \\
\text { ror }\end{array}$ & & & $\begin{array}{l}\text { Tolera } \\
\text { nce }\end{array}$ & VIF & & & & \\
\hline (Constant) & -.606 & .216 & & -2.803 & • & & & & & \\
\hline $\begin{array}{c}\text { Experienc } \\
\text { e } \\
\text { Satisfactio } \\
n\end{array}$ & 1.011 & .051 & .769 & $\begin{array}{l}19.69 \\
8 * * *\end{array}$ & 1.000 & 1.000 & $\begin{array}{c}398.735 \\
* * *\end{array}$ & .591 & .591 & 2.701 \\
\hline
\end{tabular}

In summary, entertainment, education, and deviating experience all increase experience satisfaction and have a positive effect on purchase intent. Therefore, if the three factors are high, it can be said that purchase intent is also high.

\section{Conclusion}

The result of the research proves that amongst the four factors of exhibition experience, the three factors (entertainment, educational, deviating) have a significant effect on experience satisfaction. The result of the empirical analysis means that aesthetic factors such as design, color, and lighting should be enhanced to increase the experience satisfaction of the audience, which can lead to positive behaviors, a corporation's image, and brand value. 
In addition, since entertainment, education, and deviating experience increased experience satisfaction and had a positive effect on purchase intent, if the three factors are high, it can be said that purchase intent is also high.

For the follow-up study, to provide the best exhibition experience to the audience who visit the corporate promotion exhibition hall, it needs to add different variables other than the four experience factors, including the information desk, how-to guide, etc.

\section{References}

[1] S. Y. Kim, "A study on improving exhibit Experience for Hands-on Exhibition Design," Han-Yang University, Master's Thesis, pp.8, (2014)

[2] H. J. Sin, "A study on characteristics of exposition space for the revitalization of the company brand," MyungJi University, Master's Thesis, pp.22-24, (2007)

[3] J. S. Hyeong, "Structure of exhibition scenario and space arrangement programming in the enterprise museum," Seong-Gyun-Gwna University, Master's Thesis, pp.5, (2002)

[4] S. J. Kim, "A study on the relations among experience elements, satisfaction and behavioral intention," GyeongHui University, Master's Thesis, pp.10, (2015)

[5] H. J. Gwak, "A study on a display of museum exhibition for synaesthetic experience", Hong-Ik University, Master's Thesis, pp.8, (2007)

[6] M. R. Seo, "A study of the design for the corporate PR office applying experiential economic theory and the 4Es' expressive feature," Hong-Ik University Master's Thesis, pp.15, (2012)

[7] S. U. Choe, "The influence of Theme Park Service's Experience on Brand Equity”, Han-Yang University, Master's Thesis, pp.14, (2014)

[8] J. Y. Heo and A. Choi, "A study on the corporate exhibition center visitors' behavioral intentions of experience economy theory," Seo-Gang University, Master's Thesis, pp.8-15, (2013) 